\title{
The United Nations, Self-Determination and The Namibia Opinions
}

Nation-states form from the unification of disparate groups which feel such a configuration maximizes the protection of their values. Once formed, however, the state exists in dialectic opposition to further group formation, governing elites jealously preserving their $\mathrm{ex}$ istence against the formation of groups which do not find the state supportive of their needs. Usually some accommodation is reached, but at times dissident communities demand independence or some other status which the governing elite refuses to recognize. Such demands are frequently articulated under the rubric of self-determination and raise issues of human rights which cannot be ignored.

Self-determination has not, however, traditionally been defined in this manner. Historically, international law allowed state elites to treat citizens as they saw fit. But in an interdependent world, this view has become anachronistic. There is a growing awareness that any state activity that deprives a segment of its population of its human rights is a matter of international concern. ${ }^{1}$ Even where no danger of international conflict exists, ignoring one national subgroup's brutality toward another offends basic ideas of civilization. The crematoria of Auschwitz stand as a vivid reminder of the end result of ignoring a state's actions within its own borders.

At the turn of this century, the term self-determination had some symbolic importance but lacked normative content. However, as different groups began utilizing the symbol of self-determination, the world community evolved prescriptions to deal with these growing demands. ${ }^{2}$ As new and different demands were made, some prescriptions were terminated while others, taking account of changing expectations, came to the fore. ${ }^{3}$ These new prescriptions have con-

1. For an early exposition of this concept, see H. LAUTERracit, INTERNATIoval Law AND Human RIGHTs 178 (1950). See also E. Lauterpacht, Some Concepts of Human Rights, 11 How. L.J. 264 (1965); M. Moskowitz, The Polttics and Dinamics of HumaN Ricims (1968); McDougal, Lasswell \& Chen, Human Rights and World Public Order: A Framework For Policy Oriented Inquiry, 63 A.r. J. INr'L L. 237 (1969).

2. The term prescription in this context refers to a set of expcctations about who is the appropriate decision-maker in a specific class of controversies, how that decisionmaker will deal with such controversies, and what criteria will affect his decisions.

3. For a discussion of the dynamics of the decision-making process in the international context, see McDougal, Lasswell \& Reisman, The World Constitutive Process of Authoritative Decision, 19 J. Legal ED. 253, 403, 423 (1967); M. MIcDotg.AL, H. Lisswel. \& I. Vlasic, LAw aNd Public Order in SPace Part I (1963). An authoritative decision involves 
sistently expanded the groups to which the principle of self-determination applies. However, with equal consistency other groups have opposed this extension and have sought to limit the concept of self-determination to situations which least threaten the status quo. Since 1945 this evolutionary process has occurred primarily in the General Assembly of the United Nations, the most representative body of the organized world community.

This Note has two related themes. The first is that the General Assembly has assumed an authoritative role in determining the content of the principle of self-determination. The South West Africa issue presents an excellent opportunity to examine this assertion. First at Versailles, then in Geneva, and now in New York, the status of the people of South West Africa has been a subject of almost continuous debate and of six separate Judgments and Advisory Opinions of the International Court of Justice. It thus offers an excellent opportunity to examine the role of the organized world community, in its different forms, in evolving the right of self-determination.

A critical event in the South African controversy was the 1971 Advisory Opinion of the International Court of Justice: ${ }^{4}$ The court there recognized that the primary issue regarding South Africa's continued presence in Namibia ${ }^{5}$ was its refusal to allow the Namibians the right to determine their own future, a right established by the General Assembly in its debates and resolutions. The court affirmed the inclusive role of the Assembly in determining the normative content of this right. In this sense, the Opinion represents the culmination of the anti-colonialist era, providing judicial recognition to the right of former colonies to independence.

The second theme is that the General Assembly has thus far been unwilling to expand the concept of self-determination beyond the colonial context. This Note will argue that in its broad meaning, self-determination must be viewed as the basic right of the individual to form his own associations in order to maximize his preferred interests. If it recognizes this interpretation the Assembly will

a complex of activities including intelligence gathering, recommendations of policy, pre. scription of the policy as authoritative, invocation of decision-makers when there are deviations from prescriptions, application of these prescriptions to such behavior, termi. nation of outmoded prescriptions, and an appraisal of the effects of a flow of decisions.

4. Advisory Opinion on the Legal Consequences for States of the Continued lresence of South Africa in Namibia (South West Africa) notwithstanding Security Council Reso. lution 276 (1970), [1971] I.C.J. 16 [hereinafter cited as Namibia].

5. The General Assembly changed the name of the territory of South West Africa to Namibia, the name given to the land by the insurgent groups operating against the South Africans. G.A. Res. 2372, 22 U.N. GAOR Supp. 16A, at 1, U.N. Doc. A/6176/Add. 1 (1968). 
then be able to focus on human rights problems and contribute to their solution.

I. Evolution of the Principle of Self-Determination by the Organized World Community

\section{A. The Mandate System: Sacred Trust of Civilization}

During the First World War, the Allies adopted self-determination as one of the major principles at stake in the struggle. ${ }^{\circ}$ President Wilson maintained that the principle was a necessary precondition for international peace. However, he limited application of the principle to Central and Eastern Europe and was willing to sacrifice it even there if other interests seemed more important. ${ }^{\top}$ The other powers had little sympathy for even Wilson's limited concept of selfdetermination, and the resulting peace treaties reflected the cynicism of those participants. At most, the treaties expressed a willingness to establish several new European states in order to secure a new balance of power. ${ }^{8}$ As for the overseas possessions of the defeated powers, the victors developed a plan which offered the people of those colonies not immediate self-determination but rather subjugation to a Mandate system. Although the countries chosen as Mandatories and given control over the former colonies could derive substantial benefits from the arrangement, they did have certain obligations to the indigenous populations. These were embodied in the concept of the "sacred trust of civilization."

The sacred trust concept was articulated in Article 22 of the League of Nations Covenant:

1. To those colonies and territories which as a consequence of the late war have ceased to be under the sovereignty of the States which formerly governed them and which are inhabited by peoples not yet able to stand by themselves under the strenuous conditions of the modern world, there should be applied the principle

6. The roots of the doctrine can be found in the aftermath of the religious wars of the seventeenth century, but the principle received its first modern expression during the American and French Revolutions. Sinha, Self-Determination in International Law and its Applicability to the Baltic Peoples, in Res BALTICA 256, 257-62 (A. Sprudzs \& A. Rusis eds. 1968). For the history of self-determination, see E. CARR, THE Futune OF NAtIONS: INDEPENDENCE OR INTERDEPENDENCE (1941); A. Cobban, THE Nation STate aNd NatIONAL SELF DETERAIINATION (1970); U. UMozURIKE, Self-Determination w Isitersiational Law ch. I (1972); S. Wambaugh, Plebiscrtes Since the World War (1933).

7. U. UMOzURIKE, supra note 6, at 11-26; A. ConbaN, supra note 6 , at 62-65.

8. Brown, Self-Determination in Central Europe, 14 Asr. J. INT'L L. 235, 237 (1920). 
that the well-being and development of such peoples form a sacred trust of civilization and that securities for the performance of this trust should be embodied in this Covenant.

2. The best method of giving practical effect to this principle is that the tutelage of such peoples should be entrusted to advanced nations who by reason of their resources, their experience or their geographical position can best undertake this responsibility, and who are willing to accept it, and that this tutelage should be exercised by them as Mandatories on behalf of the League. ${ }^{9}$

The International Court has grappled with the meaning of these provisions on six separate occasions, each time in the context of the South West Africa Mandate. ${ }^{10}$ One of the major questions presented in these cases has been whether the organized world community, whatever its form, could supervise the conduct of the Mandates, or whether such supervision could be exercised only by the League of Nations. Only in its Judgment of $1966^{11}$ did the court reject the contention that the sacred trust gives members of the organized world community a continuing legal interest in the conduct of the Mandates. After six years of litigation, ${ }^{12}$ an 8-7 majority held that it would not entertain a dispute between former members of the League and South Africa, the Mandatory power, over the latter's treatment of the inhabitants of the Mandate, because the petitioner states had no standing to raise the issue. ${ }^{13}$ The court stressed that though

9. League of Nations Covenant art. 22, paras. 1 \& 2.

10. During the 1950's the Court issued three Advisory Opinions: Advisory Opinion on International Status of South West Africa, [1950] I.C.J. 128 [hereinafter cited as International Status Opinion] (see pp. 538-40 infra); Advisory Opinion on South West Africa $\rightarrow$ Voting Procedure, [1955] I.C.J. 67 [hereinafter cited as Voting Procedures Opinion] (see p. 547 infra); Advisory Opinion on the Admissibility of Hearings of Petitioners by the Committee on South West Africa, [1956] I.C.J. 23 [hereinafter cited as Petitioners Opinion] (see p. 547 infra). All three stressed the role of the General Assembly as supervisor of the Mandate. In 1960, Liberia and Ethiopia, former members of the Lengtic and present members of the United Nations, brought contentious procecdings against South Africa for violations of the Mandate. The court dealt with this litigation in two phases. See notes 11-13 infra. Finally, in 1970 the Security Council asked for an Advisory Opinion on the consequences for States of the termination of the Mandatc. The result was the Namibia Opinion, which sought to draw conclusions concerning the right to selfdetermination and the role of the General Assembly in defining and protecting that right. See pp. 543-46 et seq. infra.

11. South West Africa Second Phase, Judgment, [1966] I.C.J. 6 [hereinafter cited as 1966 SWA Judgment].

12. South West Africa Cases Preliminary Objections, [1962] I.C.J. 819 [hercinafter cited as 1962 SWA Judgment].

13. 1966 SWA Judgment. The decision took much of the international community by surprise because it seemed to reverse the 1962 ruling and came after months devoted to oral and written pleadings directed solely to the merits. Six of the fourteen judges did in fact examine the compatibility of apartheid with the Mandatory's obligations to promote the welfare of the inhabitants, and only South Africa's judge ad hoc, Van Wyk, found for South Africa. Id. at 140.93 (Van Wyk, J.), 235 (Wellington Koo, J.), 315 (Tanaka, J.), 
humanitarian considerations may constitute the inspirational basis for rules of law .... [s] uch considerations do not, however, in themselves amount to rules of law .... [T] he existence of an "interest" does not of itself entail that this interest is specifically juridical in character. ${ }^{14}$

There is no doubt that humanitarian considerations gave the impetus for establishing the Mandates. Lord McNair has written:

There was perhaps no part of the Covenant that called forth more derision from the cynical and worldly-wise than the Mandates System contained in Article XXII. . . The Mandates System represents the irruption of the idealist into one of the periodical world settlements which have in the past lain too much in the hands of "practical men."15

The majority of the 1966 court failed to consider the community policies underlying the sacred trust concept, and this failure to adopt a contextual approach with policy considerations led them to ignore the crucial role that the organized world community was expected to play. While there is no doubt that in 1919 , as now, traditional international law was primarily a jus inter potestas, a law between states, events have caused radical changes in the world order. Judge Jessup has noted four major post-World War I manifestations of the recognition that all states have an interest in events occurring in any part of the world: ${ }^{16}$ Article 11 of the League Covenant, which recognized that peace is indivisible; ${ }^{17}$ treaty recognition of the interest of the

464 (Padilla Nervo, J.), $482-83$ (Forster, J.), 490 (Abanefo, judge ad hoc). Judge Spender criticized discussion on the merits in an attached Declaration. Id. at 51-57. For criticisms of the Judgment, see Higgins, The International Court and South W'est Africa: The Implications of the Judgment, 42 INT'L AFF. 573 (1966); Gross, The South West Africa Case: What Happened?, 45 Foreign Affairs 36 (1966.67); Dugard, The South West Africa Case Second Phase, 1966, 83 South African L.J. 429 (1966).

14. 1966 SWA Judgment at 34 . The court also observed:

The sacred trust, it is said, is a "sacred trust of civilization." Hence all civilized nations have an interest in seeing that it is carried out. An intercst no doubt; but in order that this interest may take on a specifically legal character, the sacred trust itself must be or become something more than a moral or humanitarian ideal .... Id. In a recent article, Alexandrowicz claims that the juridical expression of the sacred tuust concept can be found in nineteenth century bilateral treaties between European powers and African nations, and in the multilateral arrangements made at the Berlin Conference of $1884-85$. He finds that the establishment of the sacred trust is connected with the transfer by the African tribes of their sovereignty, territory, and destiny to the European colonialists. Through various transactions these European states assumed the role of guardian of the African communities. Alexandrowicz, The Sole Juridical Expression of the Sacred Trust of Civilization, 65 AM. J. INT'L L. 149 (1971).

15. MicNair, Preface to $\}$. Stoyanovsky, The Miandate for Palestine at v (1928). For a collection of the views of other scholars, see 1966 SWA Judgment at 373.38 Uessup. J., dissenting).

16. 1962 SWA Judgment at $425-33$ (Jessup, J.).

17. League of Nations Covenant art. 11 . 
international community in the protection of minorities; ${ }^{18}$ the interest of every state in the "humane conditions of labour" in all states, as propounded in the Constitution of the International Labor Organization; $;^{19}$ and, finally, Article 22 of the Covenant with its formulation of the sacred trust. ${ }^{20}$

The Mandate System instituted a novel regime with at least three important legal consequences. First, the principle of non-annexation was recognized as paramount. ${ }^{21}$ That is, normal rules concerning the acquisition and loss of territory did not apply to the Mandates. Second, Article 7 of the Mandate Agreements ${ }^{22}$ imposed a legal obligation on the Mandatories, including South Africa, to submit reports to the League, thereby conferring on the organized world community a voice in determining the rights and duties of the Mandatory with regard to the territory under its control. Finally, Article 22 of the Lengue Covenant, in describing the Mandate Agreements, explicitly proclaims concern for the peoples of the territories, thus giving them a special status. ${ }^{23}$ The result of these novel provisions was to create two new legal persons in international law-the international organization and the individual. These provisions thus served to shift the international perspective on territories under foreign domination from a concept of sovereignty to one of supervision by the organized world community.

This supervisory role was made explicit in the court's 1950 Opinion. ${ }^{24}$ The judges there agreed that the Mandate survived the dissolution of the League:

18. Article 69 of the Treaty of St. Germain, which terminated hostilitics betwecn the Allies and Austria after World War I, was the prototype for other minority treatics: "Austria agrees that the stipulations in the foregoing Articles of this Section, so far as they affect persons belonging to racial, religious or linguistic minorities, constitute obllgations of international concern ..." 3 MAJOR PEACE TREATIES OF MODERN HistokY, 1648-1967, at 1562 (F. Israel ed. 1967).

19. I.L.O. ConsT. preamble \& art. 26.

20. See pp. 535-36 supra.

21. In its Advisory Opinion of 1950 the Court recalled that when the nations set up the Mandate system,

two principles were considered to be of paramount importance: the princlple of nonannexation and the principle that the well-being and development of such peoples form a "sacred trust of civilization." International Status Opinion at 131.

22. 1 M. HudSON, INTERNATIONAL LegisLation 60 (1931).

23. League of Nations Covenant art. 22, para. 1. See Oral Statement of The Netherlands, 2 Namibia Opinion, I.C.J. pleadings 122-23 (1971) [hercinafter cited as Namibia Pleadings].

24. International Status Opinion. This decision was foreshadowed by the dissent of Judge Oda in the Mavrommatis case, dealing with the Mandate for Palestine. Judge Oda declared that provisions for the indirect supervision of the Mandate by the Pcrmancnt Court could only be initiated at the request of a member of the League, and that such an application "must be made exclusively with a view to the protection of general interests." Thus an outside state could, through the Permanent Court, intervene to assert the interest of the world community in the supervision of the sacred trust. The Mavrommatis Palestine Concessions (Jurisdiction), [1924] P. C. I. J. ser. A, No. 2, 7, at 85. 
The object of the Mandate regulated by international rules far exceeded that of contractual relations regulated by national law. The Mandate was created in the interest of the inhabitants of the territory and of humanity in general, as an international institution with an international object-a sacred trust of civilization. 25

Thus the reasons for establishing the Mandate gave it a status which had not lapsed. As the Namibia court later observed, "an institution established for the fulfillment of a sacred trust cannot be presumed to lapse before the achievement of its purpose."20 The 1950 Opinion went still further, stating that the supervisory role of the organized world community also survived in the form of obligations owed to the General Assembly, since that body performed many of the functions of the old League Council. Specifically, the majority found that Article $80(1)$ of the United Nations Charter maintained the obligations of the Mandatory, while Article 10 created the supervisory power of the Assembly. ${ }^{27}$

The dissenters from this portion of the Opinion found no legal nexus between the survival of the Mandate and the necessity to report to the Assembly, because they overlooked the importance of the sacred trust. ${ }^{28}$ At the core of the 1950 Opinion is the assertion that the sacred trust is a dynamic concept not limited by any agreement but rather dedicated to the well-being of the inhabitants of

25. International Status Opinion at 132. The court reasoned that the obligations of South Africa to "promote to the utmost the material and moral well-being and the social progress of the inhabitants under Articles 2-5 of the Mandate Agreement represented the very essence of the sacred trust," and, since their fulfillment did not depend on the existence of the League, "they could not be brought to an end merely because this supervisory organ ceased to exist." Id. at 133. Judges Read and MiNair agreed that the Mandates survived the dissolution of the League. Id. at 169 (Read, J.), 157 (Mrivair, J.).

26. Namibia at 32 .

27. International Status Opinion at 136-37. This holding was specifically approved by the court in its 1971 Advisory Opinion, Namibia at 33-37.

28. International Status Opinion at 146-92. Actually, Justice Mifair did realize its significance:

The Mandates System is a new institution-a new relationship between a territory and its inhabitants on the one hand and the government which represents them internationally on the other-a new species of international government, which does not fit into the old conception and which is alien to it. The doctrine of sovercignty has no application to this. new system. Sovereignty over a Mandated territory is in abeyance; if and when the inhabitants of the territory obtain recognition as an inde. pendent State ... sovereignty will revive and vest in the new State.

Id. at 150 (MCNair, J., dissenting) (emphasis added). Despite this statement, McNair vas not willing to preserve the administrative supervisory function of the organized world community. He believed that the Mandate System provided for both judicial and ad. ministrative supervision, and, since former members of the League still had a legal interest in the proper exercise of the Mandate and could bring to the ICJ any violations committed by the Mandatory, this was sufficient protection. One wonders how he vould have voted had he foreseen the 1966 Judgment, which denied this type of judicial supervision. 
the Mandated territories. A later court expressly interpreted the 1950 Opinion in this manner:

[T] he paramount purpose underlying the taking over by the General Assembly of the UN of the supervisory functions in respect of the Mandate for South West Africa . . . was to safeguard the sacred trust of civilization through the maintenance of effective international supervision of the administration of the Mandated Territory. ${ }^{28}$

The International Court's prescription of the supervisory powers of the organized world community did not take place in a vacuum, but rather during a time of intense international concern over problems of political and cultural independence. The court was attempting to express a new view of the sacred trust consistent with the evolving shared expectations of the international community. To understand the significance of these Opinions, one must view them in this context of world events.

\section{B. The Modern Expression of Self-Determination in the General Assembly}

Article 73 of the U.N. Gharter expands the concept of the sacred trust to all "territories whose peoples have not yet attained a full measure of self-government ...."30 The principle of self-determination appears as one of the "purposes" of the United Nations in Article $1(2)$ and is again mentioned in Article 55.31 Though these provisions expressed the hopes, more than the political realities, of the world in 1945, they represented the genesis of a new legal concept. The birth of the new nation-states of the Third World and their entry into the United Nations led to the drive against colonialism in the post-war decade. In the U.N., these new members consistently supported revolutionary movements which were rapidly driving out the colonial powers. At first, several Western states ignored these demands for

29. Petitioners Opinion at 28.

30. U.N. ChARTER art. 73. See Namibia at 31.

31. U.N. Charter art. 1, para. 2 and art. 55. For the history of these Articles, see R. Russell, History of the United Nations Charter (1958); L, Goodricil, E. Hambro \& A. Simons, Charter of the United Nations: Commentary and Documents 30 (3d and rev. ed. 1969) (Article 1). On the role of self-determination in the post World War II period, see A. Cobban, supra note 6; Emerson, The New Higher Law of Anti. Colonialism, in The Relevance of International LAw 153 (I. Deutsch \& $S$. Hoffman eds. 1968); Mensah, Self-Determination Under United Nations Auspices (1964) (unpub. lished doctoral dissertation, Yale University). For a more cynical look at the events of the past few years, see Emerson, Self-Determination, 64 AM. J. INT'L. L. 459 (1071). 
independence. To keep such sensitive matters out of U.N. debate and public view, these nations relied on the protection of Article $2(7)$ of the Charter, which reserved to the states matters essentially within their domestic jurisdiction. ${ }^{32}$ Most members, however, refused to recognize any limitation on the ability of the Assembly to discuss problems of colonialism. ${ }^{33}$

From a legal standpoint, the most important event in the fight against colonial rule was the adoption in 1960 of the Declaration on the Granting of Independence to Colonial Countries and Peoples. ${ }^{3 t}$ This Declaration, Resolution $1514(\mathrm{XV})$, embraces all peoples and territories which have not yet attained independence. It broke with past tradition by stating that lack of preparation in the political, economic, social, or educational fields could no longer "serve as a pretext for delaying independence."35 It has carried more weight than the usual Assembly recommendation and is the basis for most later pronouncements on self-determination. ${ }^{30}$ The Declaration also reflects the peculiar circumstances of colonialism. While the ideal of self-determination at Versailles was to grant independence to separate ethnic communities on the basis of common languages or cultures, in the decolonization era ethnicity is irrelevant; the main consideration is the political boundaries of the former colonial territories. Indeed, to ensure national stability in an essentially fragmented environment, the new elites of Africa have had to deny the right of

32. U.N. Charter art. 2, para. 7.

33. Thus, although France claimed that since Algeria was part of Metropolitan France the United Nations had no right to interfere, an overwhelming majority in the Assembly voted to recognize the right of the Algerian people to independence. G.A. Res. 1573, 15 U.N. GAOR Supp. 16 at 3, U.N. Doc. A/4660 (1960). For a review of the attempts to invoke Art. 2(7) in the Assembly to avoid debate on issues of self-determination and the refusal of that organ to accept such an argument, see R. Hicciss, TuE Develorusit of INTERnational LaW Through the Polttical Organs of THE UNited Nations 91-106 (1963).

34. G.A. Res. 1514, 15 U.N. GAOR Supp. 16, at 66, U.N. Doc. A/4684 (1960) [hercinafter cited as Res. $1514(\mathrm{XV})]$. See Namibia at 31 .

35. Res. $1514(\mathrm{XV})$ at 67 .

36. At its next session the General Assembly set up a committce to malie recommendations on the implementation of Res. $1514(\mathrm{XV})$ and to propose specitic measures to speed up the process. G.A. Res. 1654, 16 U.N. GAOR Supp. 17, at 65. U.N. Doc. $1 / 5100$ (1962). See also GA Resolutions 1810, 17 U.N. GAOR Supp. 17, at 72, U.N. Doc. A/5217 (1962); 1956, 18 U.N. GAOR Supp. 15, at 8, U.N. Doc. A/5515 (1963); 1970, 18 U.N. GAOR Supp. 15 , at 49, U.N. Doc. A/5515 (1963); 2105, 20 U.N. GAOR Supp. 14, at 3. U.N. Doc. A/6014 (1965); 2189, 21 U.N. GAOR Supp. 16, at 5, U.N. Doc. A/6316 (1965); 2326, 22 U.N. G.1OR Supp. 16, at 4, U.N. Doc A/6716 (1967); 2465, 23 U.N. GAOR Supp. 18, at 4. U.N. Doc. A/7218 (1968); 2548, 24 U.N. GAOR Supp. 30, at 5, U.N. Doc. A/7630 (1969); 2621, 25 U.N. GAOR Supp. 28, at 1 , U.N. Doc. A/8028 (1970). For a review of the Assembly's handling of the Algerian, Cyprus, and West Irian questions in light of the Declarntion, see L. GoodRICH, E. HAMBro \& A. Simons, supra note 31, at 32-33. Even those who looked warily at the Declaration because of its lack of specific content noted that it could not be ignored and would have significant ramifications on other areas of customany international law. R. Jennings, The Ácquisition of TerRitory 78-87 (1963). 
secession based on cultural differences, which was the essence of Wilsonian self-determination. Thus, one provision of Res. 1514 (XV) asserts that the integrity of a state's national territory shall be respected. ${ }^{37}$

After the passage of Res. 1514(XV), the increasing voting power of the Third World states in the U.N. and their growing impatience with the refusal of the Western powers to eradicate colonialism led to demands for further recognition of the right to aid oppressed peoples. Thus, General Assembly Resolution 2131 (XX) on nonintervention, which forbids not only military, but economic, political, or any other type of pressure to coerce another state as well, makes the one exception that,

All States shall respect the right of self-determination and independence of peoples and nations . . . with absolute respect to human rights and fundamental freedoms. Consequently all States shall contribute to the complete elimination of racial discrimination and colonialism in all its forms and manifestations. ${ }^{38}$

With this resolution, passed by a vote of 109-0, the representatives warned those who oppressed their populations that other states might intervene to correct the situation. Similarly, in 1966 the Assembly adopted the International Covenants On Human Rights, which declare that:

All peoples have the right of self-determination. By virtue of that right they freely determine their political status and freely pursue their economic, social and cultural development. ${ }^{30}$

Thus, in the 1960's the actions of the General Assembly not only reflected an awareness of the changing political realities, but also "symbolize[d] and concretize[d] a new politico-juridical conception: the

37. Res. $1514(\mathrm{XV})$ at 67 .

38. G.A. Res. 2131, 20 U.N. GAOR Supp. 14, at 11, U.N. Doc. A/6014 (1965), This Resolution has been criticized in Dugard, The Organization of African Unity and Colonialism: An Enquiry into the Plea of Self-Defence As a Justification For the Use of Force In the Eradication of Colonialism, 16 INT'L \& CoMp. L.Q. 157 (1967). But see Declaration on Principles of International Law concerning Friendly Relations and Co. operation among States, in accordance with the Charter of the United Nations, G.A. Res. 2625, 25 U.N. GAOR Supp. 30, at 121, U.N. Doc. A/8028 (1970), stressing the duty of states to refrain from any forcible action which might deprive peoples of their right to self-determination and entitling governments to support those peoples sceking to excrcise this right. This Declaration expresses the Third World and Communist view of the right to use force to liberate peoples under colonial domination. For more on the problein of the use of force, see note 61 infra.

39. International Covenant on Civil and Political Rights, G.A. Res. 2200, 21 U.N. GAOR Supp. 16, at 49, 53, U.N. Doc. A/6316 (1966). 
definite repudiation and end of colonialism." $\$ 0$ The history of the former Mandates reflects this change: Excluding Namibia, only two of fifteen remain under United Nations tutelage. ${ }^{41}$

The development of the right of self-determination has occurred during a period of growing concern for human rights in general and should be viewed as a reflection of this concern. The Preamble of the U.N. Charter, ${ }^{42}$ the Universal Declaration of Human Rights, ${ }^{\text {t3 }}$ the Genocide Convention, ${ }^{44}$ the Convention on the Elimination of Racial Discrimination, ${ }^{45}$ and the two Covenants on Human Rights ${ }^{40}$ represent but a few of the major documents reflecting this concern. Similarly, during its debates over Rhodesia, the Security Council established a nexus between the deprivation of human rights and threats to international peace, thus invoking its competence to declare violations of such rights. ${ }^{47}$

\section{The Namibia Opinion: From Sacred Trust to Self-Determination}

In 1971, the International Court affirmed the right of colonial peoples to independence. The immediate history of the Opinion began when the Twenty-First Session of the General Assembly convened in the fall of 1966, a few months after the ICJ had rendered its Judgment in the South West Africa Cases.8 The Assembly, reacting to what seemed an abdication of responsibility on the part of the court, ${ }^{49}$ passed Res. $2145(\mathrm{XXI})$, in which it declared:

That South Africa has failed to fulfill its obligations in respect of the administration of the Mandated Territory and to ensure the moral and material well-being and security of the indigenous inhabitants of South West Africa and has, in fact, disavowed the Mandate.

$[A] n d$ therefore ... that the Mandate conferred upon his Brit-

40. J. Castaneda, Legal Effects of U.N. Resolutions 175 (1969). A minority of com. mentators still hold that "the principle of national self-determination is a formative principle, but not yet part and parcel of international customary law." See, e.g., G. Schwartzenberger, A Manual of International Law 74 (5th ed. 1967).

41. In part, the decolonization process was hastened by the awareness of several of the Western powers that they could surrender political control over these territories while maintaining economic domination.

42. U.N. Charter preamble.

43. G.A. Res. 217, U.N. Doc, $A / 810$ at 71 (1948).

44. Adopted by G.A. Res. 260, U.N. Doc. A/810 at 174 (1948).

45. Adopted by G.A. Res. 2106, 20 U.N. GAOR Supp. 14, at 47, U.N. Doc $\$ / 6014$ (1965).

46. See p. 542 and note 39 supra.

47. See McDougal \& Reisman, Rhodesia and the United Nations: The Law/ulness of International Concern, 62 AMr. J. INT'L L. 1, 13-19 (1968).

48. See pp. 536-37 supra.

49. See p. 554 infra. 
tanic Majesty to be exercised on his behalf by the Government of the Union of South Africa is therefore terminated, that South Africa has no other right to administer the Territory and that henceforth South West Africa comes under the direct responsibility of the United Nations. ${ }^{50}$

South Africa ignored the resolution and instituted a course of action designed to annex the territory. The Praetoria Government arrested and tried over thirty Namibian political leaders, an act which the Assembly and Security Council viewed as a direct violation of Res. 2145(XXI), since the termination of the Mandate meant that South Africa no longer had authority within the territory. ${ }^{51}$ South Africa then began implementing the Odendaal plan to establish "homelands" for the black and colored populations in the barren parts of Namibia. ${ }^{52}$ The Security Council responded by passing Res. 276 (1970), which declared,

that the continued presence of South African authorities in Namibia is illegal and that consequently all acts taken by the Government of South Africa on behalf or concerning Namibia after the termination of the Mandate are illegal and invalid ....

and called,

upon all States, particularly those which have economic and other interests in Namibia, to refrain from any dealings with the Government of South Africa which are inconsistent with ... the present resolution. ${ }^{63}$

At its next session, the Security Council asked the International Court for an Advisory Opinion on the consequences of the continued presence of South Africa in Namibia. ${ }^{54}$ The court, however, devoted

50. G.A. Res. 2145, 21 U.N. GAOR Supp. 16, at 2, U.N. Doc. A/6316 (1966).

51. See S.C. Resolutions 245, 246, 23 U.N. SCOR, 1387th meeting 1, 2 (1968); G.A. Res. 2324, 22 U.N. GAOR Supp. 16, at 3, U.N. Doc. A/6716 (1967); G.A. Res. 2325, 22 U.N. GAOR Supp. 16, at 3, U.N. Doc. A/6716 (1967).

52. U. UMozURIKE, supra note 6, at 133-37.

53. S.C. Res. 276, 25 U.N. SCOR, 1529th meeting 1 (1970). The delegates vicwed this resolution as a compromise which could give the United Nations a productive role with. out splitting the membership over the question of the use of force against South Africa. See note 61 infra.

54. S.C. Res. 284,25 U.N. SCOR, 1550th meeting 4 (1970). The strange wording of the request resulted from the fear that if the judges were allowed to rule on the valiclity of the termination of the Mandate they might consider Res. 2145(XXI) and Res. 276 (1970) ultra vires; the bitter taste of the 1966 Judgment still lingered. For the court's reply, see Namibia at 45 .

The court held by 13 votes to 2 :

1) that, the continued presence of South Africa in Namibia being illegal, South Africa is under obligation to withdraw its administration from Namibia immediately and thus put an end to its occupation of the territory;

by 11 votes to 4 ,

2) that States Members of the United Nations are under obligation to recognize the 
most of the substantive part of the Opinion to a review of the events precipitating the revocation of the Mandate. The Council had not requested such a review nor did the court add any new information to that contained in its previous Opinions. Rather, the judges embarked on this historical survey, stressing the uniqueness of the sacred trust concept, the emergence of the United Nations, and the significance of pronouncements such as Res. 1514 (XV), in order to provide a basis for the Assembly's revocation: its authority to apply the right of self-determination to particular situations. The court made it clear that by 1966, the year of the revocation, the evolving sacred trust concept required granting of the right of self-determination to the Namibian people:

Mindful as it is of the primary necessity of interpreting an instrument in accordance with the intentions of the parties at the time of its conclusion, the Court is bound to take into account the fact that the concepts embodied in Art. 22 of the Covenant ... . were not static, but were by definition evolutionary, as also therefore, was the concept of the "sacred trust"... [I] interpretation cannot remain unaffected by the subsequent development of law, through the Charter of the United Nations and by way of customary law. Moreover, an international instrument has to be interpreted and applied within the framework of the entire legal system prevailing at the time of the interpretation. In the domain to which the present proceedings relate, the last fifty years ... have brought important developments.

illegality of South Africa's presence in Namibia and the invalidity of its acts on behalf of or concerning Namibia, and to refrain from any acts and in particular any dealings with the Government of South Africa implying recognition of the legality of, or lending support or assistance to, such presence and administration;

3) that it is incumbent upon States which are not Members of the United Nations to give assistance, within the scope of subparagraph 2 above, in the action which has been taken by the United Nations with regard to Namibia. Namibia at 58 .

The case has many procedural pathologies, the worst being the refusal to seat an ad hoc judge from South Africa and the refusal of some of the members of the court to step down because they had taken part in events critical to the determination of the court. These decisions, which would not have affected the outcome, represented serious tactical blunders. As Judge Onjeama put it in his Separate Opinion, South Africa's re. quests should have prevailed "so that justice may not only be done but manifestly be seen to be done." Id. at 140 . With a member of the court of their own choosing to represent their point of view to the rest of the judges, South Africa would have found it harder to ignore the Opinion, particularly since the appointment of an ad hoc judge would have drawn the case closer to contentious proceedings which are binding on the participants. On the question of the ad hoc judge, see id. at 152.53 (Dillard, J.), 139-41 (Onyeama, J.), 308-17 (Fitzmaurice, J.), 324-31 (Gros, J., dissenting). See also Gordon, Old Orthodoxies Amid New Experiences: The South West Africa (Namibia) Litigation and the Uncertain Jurisprudence of the International Court of Justice, 1 DeNver J. INT'L L. \& Policy 65, 86-87 (1971). For the reaction of South African leaders to the Opinion, see Dugard, The Opinions on South IVest Africa (Namibia): The Teleologists Triumph, 88 SOUTH African L.J. 460 (1971). 
These developments leave little doubt that the ultimale objective of the sacred trust was the self-determination and independence of the peoples concerned. In this domain, as elsewherc, the corpus juris gentium has been considerably enriched, and this the Court, if it is faithfully to discharge its function, may not ignore. ${ }^{55}$

Viewed in this light, the other Opinions of the court concerning South West Africa become clear. With the exception of the 1966 Judgment, ${ }^{56}$ all concern themselves with the ability of the General Assembly to supervise South Africa's administration of the territory. In 1950, the court decided the central question in the Assembly's

55. Namibia at 31-32 (emphasis added). This approach to treaty interpretation is compatible with Art. 31 of the 1969 Vienna Convention on Treatics:

A treaty shall be interpreted in good faith in accordance with the ordinary meaning to be given to the terms of the treaty in their context and in the light of its object and purpose.

Whether one uses a contextual approach or stresses the intentions of the partics, the function of any applier is to secure a set of results which contributes to the major goals of the entire system of which the applier is a part. As Reisman notes:

[W] here interpretation is recognized as a broad contextual function, the judge or any other applier seised of the case becomes a dominant participant in the decision. Where a constricted notion of interpretation reigns, the immediate applier's creativity is limited, but the initial prescriber's intentions are not necessarily maximized, for the application of a prescription without a creative mind able 10 fashion it to fit the needs of the current context vouchsafes at best accidental conformity with the ratio legis.

W. ReIsMan, Nullity and Revision: The Review and ENForcement of INTERNATIONAL JUDGMENTS AND AwARDS 195 (1970). This is especially so when events subsequent to the agreement so change the circumstances surrounding it as to make attempts to recapturc the original expectations of the parties impossible. These changes impose a shift "from a textual analysis to one which stresses the obligations and purposes of the engagement in the light of the total context in which the engagement was located." Namibia at 157 (Dillard, J.). See Dugard, supra note 43, and Dugard, Namibia (South West Africa): 'The Court's Opinion, South Africa's Response, and Prospects for the Future, 11 CouUM. J. of Transnat'L L. 14 (1972), attempting to explain this approach to the South Africans, who are extreme textualists.

56. The 1966 majority used a strict textual approach to avoid reaching the merits:

[The Court] must place itself at the point in time when the mandates system was being instituted, and when the instruments of the mandate werc being framed. The

Court must have regard to the situation as it was at that time. . . Intentions that might have been formed if the Mandate had been framed at a much later datc, and in the knowledge of circumstances, such as the eventual dissolution of the Leaguc and its aftermath .... are not relevant.

1966 SWA Judgment at 23. See also Namibia at 235, 241 (Fitzmaurice, J., dissenting). In the view of the majority of writers and of the legislative history of the vienna Convention, this approach to the interpretation of treaties must be rejected. See M. McDougst, H.

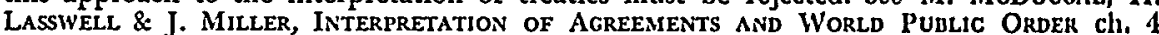
(1967), for a critique of the plain terms rule. See also A. McNatr, Tite Law of Treaties $364-93$ (1961); Statement of Sir Humphry Waldock explaining Art. 31 of the Vienna Convention on the Law of Treaties, U.N. Conference On the Law of Treaties, 1st sess., U.N. Doc. A/Conf.39/11, at 184 (1968). The court itself had rejected a rigid mode of inter* preting the Mandate Agreement only four years earlier:

- [T] his rule of interpretation is not an absolute one. Where such a method of inter. pretation results in a meaning incompatible with the spirit, purpose and context of the clause or instrument in which the words are contained, no reliance can be validly placed on it.

1962 SWA Judgment at 336. 
favor-that is, that it succeeded the League as supervisor of the Mandates. To reach this conclusion, the court had to emphasize the sacred trust concept, since there was no express succession provision transferring these powers from the League to the U.N. The judges could not, in 1950, rest the Assembly's power on its right to decide questions of self-determination, because the Assembly had not yet developed its competence in this area. There was, however, a sufficient distrust of the continuance of the white man's burden for the world community to demand a continuing voice in the administration of the territories.

In 1955, South Africa .objected that, contrary to the 1950 Opinion, supervision by the Assembly was more onerous than that exercised by the League Council. In the Council, the passage of a resolution required a unanimous vote, whereas the Assembly requires at most only two-thirds approval. However, the court brushed aside this contention, holding that the 1950 Opinion dealt with the substantive degree of supervision, whereas the voting provision related merely to the procedures of the organization. ${ }^{57}$

The next year, in the Petitioners case, South Africa argued that the 1950 Opinion was intended to limit the degree of supervision exercised by the General Assembly to that actually undertaken by the League Council. The court rejected such a reading, finding nothing in the Covenant, the Charter, or any other instrument to so restrict the Assembly's authority. Nor could the court find any justification for assuming that the transfer of the supervisory authority formerly exercised by the League had the effect of crystallizing the Mandates System at the point it had reached in 1946.58

Viewing these cases with the benefit of hindsight, ore can see the court grappling with the problem of preserving the power of the Assembly, intuitively feeling that this body had the right to make determinations concerning the Mandate. The court therefore avoided, as much as possible, a strict interpretation of the Mandate Agreement which might have left South Africa free to annex Namibia.

57. Voting Procedures Opinion.

58. Petitioners Opinion at 29. In his Separate Opinion Judge Lauterpacht viewed the degree of supervision in its entirety. He admitted that the procedure of oral hearings "connotes in itself a degree of supervision of a stringency greater than that obtaining in the matter of petitions under the Mandates System." However, he noted that as a result of South Africa's refusal to submit reports, as required by the 1950 Opinion, supervision was reduced in that respect. He therefore concluded that "the total effeet will not result in exceeding the degree of supervision as a wholc." Id. at 45-46. Thus, Lauterpacht took account of an element not contemplated by the original parties in order to make supervision effective in terms of modern expectations. 
Now that the court has given judicial recognition to the nexus established by the General Assembly between the contemporary definition of self-determination and the inchoate sacred trust concept, there is no longer any problem in justifying the actions of the Assembly. When South Africa signed the Mandate Agreement it declared its willingness to participate in a process of international legislation; it did not enter into a treaty whereby it relinquished part of its sovereignty. While in agreements of this latter type derogations from sovereignty are construed narrowly, with treaties of the former type any solution must be compatible with the basic premises of the agreement. ${ }^{59}$ Since no question of sovereignty intervenes, the powers of the Mandatory and those of the supervisory authority are limited to those which will achieve the ultimate goal of the Mandate Agreement-formerly the fulfillment of the sacred trust, now the granting of self-determination. Moreover, once the primacy of this goal is recognized, it necessarily follows that territories such as South West Africa come under international control, the modalities of which are to be determined by the international community organized in the United Nations.

\section{The Role of the General Assembly as Decision-maker}

From where does the General Assembly derive its authority to make dispositive statements on self-determination? The original framers of the U.N. Charter gave most of the decision making authority to the Security Council, ensuring the major powers a veto in important issues. The Council has the competence to deal with any issue of self-determination, based on its "primary responsibility for the maintenance of international peace and security." 00 For ex-

59. This analysis follows that used by the Netherlands, 2 Namibia Pleadings at 128.80, and may be illustrated by comparing the Mandate Agreements with the Advisory Opinion on the Interpretation of Peace Treaties, [1950] X.C.J. 229. In the Peace Treaties case the court declined to hold that the failure of a state to appoint representatives to the Com: missions which were provided for by the treaties for the settlement of disputes justifled an alternative method of appointment not contemplated by these treaties. In his opinion interpreting the Mandate Agreement, Judge Lauterpacht explained the difference between that result and the result when dealing with the Mandate as the absence of agreement in the former to endow those treaties with total effectiveness. Petitioners Opinion at 58. In oral pleadings before the Namibia Court, the Netherlands offered a more basic dis. tinction: The peace treaty regulations of the settlement of disputes werc limitations on the sovereignty of states to which those states consented. The Mandate System starts from the opposite point of view; from the functional powers of the organized community of states in relation to the regulation of the right of self-determination of peoples. 2 Namibia Pleadings at 127-28.

60. U.N. ChaRTER art. 24, para. 1. 
ample, South Africa's treatment of the Namibian population has triggered a threat to international order: The application of apartheid and the implementation of the Odendaal plan have angered other states to the point of endorsing guerrilla groups seeking to liberate the territory. ${ }^{61}$ In this case, the granting of basic human rights to the Namibian people is a minimum condition for peace.02

In such a situation, the offending state cannot limit the Council by invoking domestic jurisdiction, first, because Article 2(7) of the Charter has in practice no effect where international peace is threatened, ${ }^{63}$ and, second, because the systematic suppression of human rights violates one of the fundamental purposes of the Charter and is therefore of international concern. Nor could the state object that the Charter restricted the Council's authority to a very narrow area of decision making. ${ }^{64}$ The Namibia court held that the "only limi-

61. The Charter of the Organization of African Unity proclaims as one of the aims of the Organization the eradication of "all forms of colonialism" Irom Africa. OA.U. ChARTER art. 2(i)(d), and demands of its members "absolute dedication to the total emancipation of the African territories which are still dependent," O.A.U. Cularter art. 3(6). Despite the hostility of several of the Western powers to the use of force for such purposes, the Assembly recently voted overwhelmingly to recognize the legitimacy of armed struggle against colonialism. Ninety-nine nations voted to approve the resolution with only South Africa, Portugal, the United States, Britain, and France opposed. N.Y. Times, Nov. 5, 1972, § 1, at 10, col. 1 .

These same tensions between the Western powers and the Communist and Third World states came to the fore during the Assembly and Council debates on Namibia. The British warned the African nations that resolutions without sanctions would be ineffective. 23 U.N. SCOR, 1465th meeting 31 (1968). The French representative vent further, con. demning Res. $2145(\mathrm{XXI})$ on the ground that it might actually encourage South Afriea to annex the territory. 23 U.N. SCOR, 1465th meeting 46.52 (1968). The African delegates did not heed the warning. In S.C. Res. 269, 24 U.N. SCOR, 1497th meeting 2 (1969) they invoked Art. 25 of the Charter, characterized the continued occupation of Namibia as "aggressive encroachment," and set a time limit for withdrawal. France, the United States, the United Kingdom, and Finland abstained. During the debates over Res. 276 (1970) in the following year, Zambia bitterly attacked the Western powers for their economic and military aid to South Africa. Their delegate compared the negative attitude of these states toward issues concerning Southern Africa with the expulsion of Greece from the Council of Europe by some of these same governments, asking, "is oppression objectionable only when the victims are of European stock?" By passing Res. 270 the delegates hoped to break this deadlock, and all the delegates recognized its compromisory nature. 25 U.N. SCOR 1527th meeting 3-10 (1970). Perhaps they heeded the sobering reflection of Terence of Burundi, president of the Security Council for that month:

I must remind the Council that the United Nations is approaching the age at which the League of Nations succumbed to the weight of its impotence. The Security Council, which is the equivalent of the Council of the League of Nations [,] could not wish to be responsible for leading our Organization towards the fate of its predecessor. Id. at 3 (1970).

62. See Reisman, Responses to Crimes of Discrimination and Genocide: An Appraisal of the Convention on the Elimination of Racial Discrimination, 1 DEvive J. INT'L L. 29, 40 (1971).

63. See note 2 supra. See also MicDougal \& Reisman, supra note 47, at 13-19. The domestic jurisdiction concept has never been an absolute one. Sec also Adisory Opinion on Tunis and Morocco Nationality Decrees, [1923] P.C.I.J., ser. B, No. 4.

64. Such a view relies on the wording of Article $24(2)$ of the Charter:

The specific powers granted to the Security Council for the discharge of these duties are laid down in Chapters VI, VII, VIII, and XII.

The practice of the Council has followed a broader view of its competence. See 2 RERER. TORY OF UNITED Nations Practice 19-25 (1955). See also note 59 in, ra. 
tations [on that authority] are the fundamental principles and purposes found in Chapter I of the Charter." 05 Furthermore, the Council has the power to bind members of the U.N. to cooperate in enforcing its decisions. ${ }^{66}$

By contrast, the Charter originally intended to limit the more representative General Assembly primarily to recommendatory powers. In the Namibia Opinion, however, the court explicitly held:

[I]t would not be correct to assume that, because the General Assembly is in principle vested with recommendatory powers, it is debarred from adopting, in specific cases within the framework of its competence, resolutions which make determinations or have operative design. ${ }^{67}$

This is all the court said on the matter, though the statement may well have momentous consequences for the balance of power between the organs of the U.N. According to the Opinion, the Assembly "enlisted the cooperation of the Security Council" after terminating the Mandate. The Council was called upon to enforce the decision of the Assembly, not to transform a mere recommendation into a binding decision. Thus, in this instance, the Assembly's role assumes a position of at least equal importance to that of the Council.

Formalistic distinctions between recommendations and decisions are futile. ${ }^{88}$ The relationship between the Assembly and the Council has not been static, the former taking on more responsibility as the latter has failed to promote the aims of the Charter due to the antagonisms between East and West and the continuing use of the veto. The Uniting for Peace Resolution and the subsequent peacekeeping operations in Korea, the Middle East, and the Congo provide the most dramatic examples of the shift of responsibility-a shift recognized by the International Court. ${ }^{60}$ The Assembly is clearly no

65. Namibia at 52. See 2 Repertory of United Natrons Practice 19.25 (1955), on the responsibility the Council assumed under the statute of the Frce Territory of Trieste.

66. Namibia at 52. The court refused to limit the application of Art. 25 of the Charter, under which Member states "agree to accept and carry out the decisions of the Security Council," to enforcement actions under Chapter VII, applying it instead to all decisions of the Council adopted in accordance with the Charter which the Council meant to be determinative. This view conforms both with the placement of the Article after Art. 24 instead of in Chapter VII, and with the practice of the Council. See Higgins, The Advisory Opinion on Namibia: Which U.N. Resolutions Are Binding under Article 25 of the Charter?, 21 INT'L \& CoMP. L.Q. 270 (1972). Concerning the actions taken by the Council in the Congo operations under Art. 25 without invoking Chapter VII, sce L. GoOdrich, E. HAMbro \& A. Simon, supra note 31, at 210-11.

67. Namibia at $\mathbf{5 0 .}$

68. J. Castaneda, supra note 40. See also M. Whiteman, 13 Digest of INT'L L. 527.86 (1968).

69. Advisory Opinion on Certain Expenses of the United Nations, [1962] I.C.J. 151 [hereinafter cited as Expenses Case]. 
longer "the ears and eyes and mouth of the Organization but not the Hands."70

There are, however, checks on the transfer of power from the Council. The refusal of the Soviet Union and France to adhere to the Expenses Opinion, which gave the Assembly the power to apportion the costs of the peacekeeping operations among the members, and the acquiescence of the United States in this refusal, demonstrates that such transfers will be impossible without the support of the major powers. ${ }^{71}$

The above analysis illustrates the dynamics of the international decision making process. A series of Assembly resolutions can create the expectation that they represent the normative standard to be followed. During the 1960s, such expectations were ergendered among effective elites as to the resolutions concerning self-determination. Government officials, revolutionary leaders, and scholars came to justify their policies in terms of the Assembly's current definition of self-determination: the right to independence from colonial rule. A uniform pattern developed which raised these resolutions to the level of prescriptions; the general policy advocated was crystallized in continuing community expectations. In this sense, the pronouncements of the Assembly on self-determination became authoritative.

But not every recommendation is prescriptive. Decision-makers often misread the expectations of the community. Such was the aftermath of the Expenses case. Several major participants refused to recognize the authoritative voice of the Assembly, forcing a reassessment of the initial resolutions.

Perhaps the best judicial statement on the complex nature of Assembly recommendations is that of Judge Lauterpacht in the Voting Procedures case. He refused to accept the view that such recommendations have no significance whatever and placed a good faith requirement on all members to adhere to them.

[A] State may not be acting illegally by declining to act upon a recommendation or series of recommendations on the same subject. But in doing so it acts at its peril when a point is reached when the cumulative effect of the persistent disregard of the articulate opinion of the Organization is such as to foster the

70. L. Goodrich \& E. HaMbro, Charter of the United NathoNs 95 (1910).

71. Another Opinion of the ICJ, Advisory Opinion on Conditions of Admissions of a State to Membership in the United Nations, [1948] I.C.J. 57 [hereinafter cited as Admissions Case], was ignored when the "packige deal" resulted in the admission of many states to the United Nations without regard to the critcria set out in Article 4 of the Charter. 
conviction that the State in question has become guilty of disloyalty to the Principles and Purposes of the Charter. Thus an Administering State which consistently sets itself above the solemnly and repeatedly expressed judgment of the Organization ... may find that it has overstepped the imperceptible line between impropriety and illegality, between discretion and arbitrariness, between the exercise of the legal right to disregard the recommendation and the abuse of that right, and that it has exposed itself to consequences legitimately following as a legal sanction. ${ }^{72}$

Thus, in certain contexts a resolution or series of resolutions assumes a prescriptive or quasi-legislative role by generating a consensus that it constitutes a source of law binding on all parties. ${ }^{73}$ The termination of South Africa's Mandate binds all states because it is based on a consensus achieved over time that the Assembly has the authority to decide that South Africa has violated its obligation to ensure the Namibian people the opportunity to exercise the right of self-determination.

Not all the judges on the Namibia court agreed to so broad a view of the Assembly's competence. ${ }^{74}$ Some sought to limit its authority to matters concerning the Mandate System. Thus, Judge Dillard, in his separate Opinion, offers two alternative explanations for the court's statement on the authority of the Assembly. The first stresses that the termination of the Mandate reposes in one of the limited areas in which the Assembly has decision-making competence, an area that is sui generis. As Dillard notes, this approach bases termination on the special powers granted under the Mandate Agreement rather than in the Assembly's general powers under the Charter. ${ }^{75}$ The As-

72. Voting Procedures Opinion at 120.

73. Bleicher, The Legal Significance of Re-Citation of General Assembly Resolulions, 63 AM. J. INT'L L. 444 (1969); R. Higcins, supra note 33, at 1-10.

74. For articles taking a traditional approach to the Namibia Opinion, sce Lissitzyn, International Law and the Advisory Opinion on Namibia, 11 Colum. J. TransNat'L L. 50 (1972); Rovine, The World Court Opinion on Namibia, 11 ColUM. J. 'TrANsNart'L 1. 203 (1972). Even Lissitzyn, however, recognized the importance of self-determination and the Assembly's authoritative role in this area. Lissitzyn, supra, at 58, 66. The article most critical of the Namibia Opinion is Acheson \& Marshall, Applying Dr. Johnson's Advice, 11 Colvar. J. TransnaT'L L. 193 (1972). These two commentators support South Africa's claims on naked power concepts alone and ignore modern developments in international law.

75. Namibia at 163-64. See also the Declaration of Zafrulla Kahn, id. at 61, who believed that the Assembly's powers were greater under the Mandate Agrcement than under the Charter. This presupposes a static view of the interpretation of a constitucnt instrument. For a more dynamic view, see Admissions Case at 68-71 (Alverez, J.); Expense's Case at 186-87 (Spender, J.); Rosenne, Is the Constitution of an International Organization an International Treaty?, 12 Comunicazioni E. Studi 23, 50.80 (1966). Cf. ViENnA ConvENTION ON THE LAW OF TREATIES art. 5. 
sembly has a right of revocation because of South Africa's refusal to submit reports to the Assembly, a material breach of a treaty in force.

Alternatively, Dillard suggests that Res. 2145 (XXI) was binding insofar as it constituted the collective will of those who supported it, but had only recommendatory effect on nonconsenting States. Thus, although the Assembly could validly terminate the Mandate, it had no right to force South Africa to withdraw from the territory or to demand the cooperation of other member states in effecting such a withdrawal. For this reason, it was necessary for the Security Council to convert the recommendation into a decision operative against even nonconsenting states. ${ }^{78}$

These interpretations ignore the crucial point in the majority's reasoning. When questions of self-determination come before the Assembly, it speaks authoritatively, the authority deriving from the member states who have recognized that the Assembly's resolutions on self-determination express their own shared expectations. It is in this context that the court's lengthy statement on the evolution of the right of self-determination becomes important-it sets the groundwork for invoking the special responsibility of the world community as organized in the General Assembly, and gives normative status to resolutions originally regarded as merely precatory. The court recognizes that the acts of the Assembly since the passage of Resolution $1514(\mathrm{XV})$ have converted the Charter's general statements on selfdetermination from mere expressions of hope to a general right under international law. ${ }^{77}$ The Assembly could terminate the Mandate due to South Africa's noncompliance with its obligation as a signatory to the Charter to promote self-determination in Namibia. ${ }^{78}$ Since the Assembly is merely applying rules of law in this area, no state may base noncompliance on its abstention or nonmembership. ${ }^{70}$

There is no doubt that the delegates who passed Res. 2145(XXI)

76. Namibia at 164. Dillard favored the first explanation. Cf. The Written Statement of the Government of the United States of America, I Namibia Pleadings at 852-71 (10 INT'L Legal DIATERIAts 314) (1971). Compare the dissent of Judge Gros in Namibia at 339-40, which is typical of the strict construction that the French give to treaty interpretation and consistent with that nation's position in the Expenses case.

77. See C. PARry, The Sources and Evidences of International LAw 21.22 (1965).

78. See Written Statement by the Netherlands, I Namibia Pleadings at 350.54 (10 INT'L LEGAL MATERIALS 295, 296-99 (1971)), which gives a modificd version of this approach. There is no problem in this instance of distinguishing between sein and sollem: what is and what ought to be. As noted in the Expenses case, action of U.N. organs taken in conformity with the purposes of the Charter are not ultra vires the Organization eren if beyond the competence of the particular organ. The problem is not whether the Assembly had a right to pass Res. $2145(\mathrm{XXI})$ but only what legal effect should be given to it.

79. For Judge Gros' question on the effects of reservations to Res. $2145(\mathrm{XXI})$ and the narrow answer given by the representative of the Secretary General, see 1 Namibia Plead. ings at 479.81 . 
felt that the Assembly had the right to revoke the Mandate without waiting for court or Council action. After the frustrations of the 1966 Judgment, most felt that "it has become urgent that some positive action be taken within this Organization" and that the Assembly could terminate the Mandate as it was particularly suited to deal with such political problems. ${ }^{80}$ The Zambian representative observed that "the real issue is moral, humanitarian, and political," 11 and the representative from Mali stated that "a nation's future cannot be placed in the hands of a jurist . . . but must depend on political judgment and choice adopted judiciously. ..." 82 Others felt that the 1966 Judgment itself stressed the political nature of the problem so heavily "that even the most scrupulous concern for legal niceties may at this juncture cede its place to the political wisdom of the majority of the General Assembly." 83 Even the delegates not totally satisfied with the resolution from a technical standpoint voted for it, since they felt the Assembly had a duty to take some action to alter the status quo in southern Africa. ${ }^{84}$ The debates thus revealed an awareness of the Assembly's special responsibility to deal with the problem. By terminating the Mandate, the Assembly continued down the path chosen in 1960 when it adopted Res. 1514(XV) and asserted its competence to help oppressed people achieve freedom.

III. Ramifications of the General Assembly's Role in Dealing with Self-Determination

The General Assembly's significant role in the development of the modern concept of self-determination has thus evolved from that

80. Nigeria, 21 U.N. GAOR, U.N. DOC.A/pv 1429 at 3 (1966) [hercinafter all cites refer to the twenty-first scssion of the Assembly and will be citcd by mecting numbers and page]. See also Libya, A/PV 1425 at 8, Ivory Coast, A/PV 1429 at 16. The Sovict Union reserved para. 3 of the Resolution as it did not feel that South Africa had repudiated the Mandate, but voted for the Resolution on the ground that the "pcople of the Territory must be emancipated from South Africa's racist oppression." $A / P V 1454$ at 28-29. See also A/PV 1425 at 13.

81. A/PV 1425 at 1 .

82. A/PV 1433 at 6. See also Greece, A/PV 1425 at 12, A/PV 1454 at 17.

83. Israel A/PV 1439 at 10. See also Yugoslavia, A/PV 1454 at 14; Somalia, A/PV 1427 at 3 .

84. Several states felt that the General Assembly had legal competence to terminate the Mandate but would have liked judicial clarification. See Belgium, A/PV 1454 at 81; Canada, A/PV 1433 at 5; New Zealand, A/PV 1439 at 11, 13. Japan, without wishing to minimize the political aspects involved, felt that many legal questions remained unanswered, including pacta sunt servanda in relation to the Mandate Agrement, the legal nature and scope of human rights, and the legal machinery for the succession of the U.N. to the League of Nations. Japan suggested that the Assembly ask the ICJ for an advisory Opinion on whether apartheid was contrary to the provisions of the Mandate or Art. 73 of the Charter. Japan, A/1419 at 14-18. See also Netherlands, A/PV 1454 at 9. 
body's expression of anti-colonial views which have come to have prescriptive authority in the world community. In the future, however, the problem of self-determination is likely to arise in different contexts. Secessionist groups have already attempted to carve their own areas out of existing states. Other groups clamor not for independence but for some greater role in the body politic. All of these movements use the term "self-determination" to justify their actions.

The Assembly will have to confront these new developments for the same reasons that forced it to deal with colonialism: The U.N. exists to "save succeeding generations from the scourge of war," to "reaffirm faith in fundamental human rights," and to "promote social progress." 85 If it cannot successfully deal with new situations as they arise, the U.N. will lose the principal reason for its existence.

There is no reason to limit the applicability of the Assembly's pronouncements on self-determination to the colonial phenomenon. ${ }^{80}$ That phenomenon encompasses but a small part of the broader goal of allowing all people the right to determine their own future. The creative role that lies ahead for the General Assembly involves the expansion of this right and the determination of its expanded content. To accomplish this task, the Assembly must develop a greater sensitivity to the problems of oppressed minorities within the present state system. ${ }^{8 \pi}$ Such an evolution will undoubtedly evoke strong opposition. ${ }^{88}$ In this regard one cannot overemphasize the antithetical nature of a state-centered system to the development of a homocentric one. Self-determination poses great dangers to the state-orient-

85. U.N. Charter preamble.

86. If principles of authority are to control the flow of decision, it is ultimately essential that they be embedded in the expectations of the effective participants in the world community. At no time can it be taken for granted that human expectations ... are unchanging. Nor can it be validly asserted, without appropriate verification, that the words of treaties or other written documents mirror community expectations. Since viewpoints are in flux, today's structure of expectation is open to change, and in fact is found to change, as new conditions arise and new sug. gestions are put forward and assimilated.

M. MícDougal, H. Lassivell \& I. Vlasic, supra note 3, at 146.

87. See Houbem, Principles of International Law Concerning Friendly Relations and Cooperation Among States, 61 Ax. J. INT'L L. 703, 724-25 (1967). In 1961, during a debate over the question of Tibet, the representative of the then Federation of Malaja shoved that there was a realization of this broader concept of sclf-determination:

When we raise our voice against colonialism and violation of human rights in Africa, we are not doing so simply because the victims are Africans and the oppressors are the western colonial powers, but basically because these are questions involving the domination and suppression of man by man.

16 U.N. GAOR Doc. A/PV1084 at 146 (1961). See also the speech of the U.S. representative in this same debate, linking self-determination and human rights. Id. at 1123 .

88. The unwillingness of the Assembly to alter the present state system is demonstrated by the harsh attitude taken toward India for its invasion of East Pakistan, despite the plight of the Bengali people. 
ed status quo, and the decisions of the Assembly in the next few years will most likely reflect a determination to preserve the state system in its present form. ${ }^{80}$

But this should not necessarily give rise to despair. There appears to be an increasing awareness of the necessity for establishing basic standards of human rights to ensure a stable system in which international peace is possible. ${ }^{00}$ At the moment, self-determination seems limited to colonial peoples and to those groups who succeed by force in separating themselves from their parent states: Bangla Desh achieves recognition as a new nation, while Biafra is reabsorbed into Nigeria. New groups, however, continue to emerge and demand recognition from the world community. Not all of these deserve recognition, nor does self-determination necessarily involve the atomization of states. The Assembly will have to evolve rational criteria for determining the rights of each group in the context of the goals of the entire community, ${ }^{21}$ most notably the maximization of human dignity ${ }^{92}$ In implementing these goals, the Assembly can select from a variety of techniques. In one instance, it may call for greater eco. nomic equality or more political participation. In another, it might

89. Even in the Soviet Union, new voices in favor of human rights are being heard. In his Nobel Lecture, Soviet novelist Aleksandr Solzhenitsyn criticized the performance of the U.N. in promoting human rights:

It is not a U.N. Organization but a United Governments' Organization in which governments freely elected are equated with those which have imposed themselves by force, which seized power by force of arms. With self-seeking partiality the majority in U.N.O. concerns itself jealously for the freedom of certain peoples and leaves that of others in a state of neglect. By an obsequious vote it has rejected consideration of private complaints-the groans, the cries, the prayers of isolated little people who are merely people. To such a great organization these are mercly insects. The U.N. has never tried to make obligatory for governments as a condition of their membership the best document of its 25 years-the Declaration of Human Rightsand thus, it has consigned the little people to the will of governments they did not elect.

N.Y. Times, Oct. 7, 1972, at 33, col. 3 .

90. Solzhenitsyn also maintained that:

no such thing as internal affairs remains on our carth. And the only salvation of

humanity lies in everyone concerning himself with everything everywhere: the peo. ples of the East cannot be totally indifferent to what takes place in the West; and the peoples of the West cannot be totally indifferent to what takes place in the East. Id. at 33, col. 4. See also E. Lauterpacht, supra note 1, at 270.71; Reisman, supra note 62 .

91. The inadequacy of the present definition of self-determination is demonstrated by U. UMOZURIKE, supra note 6, at ch. 8. Especially unhelpful are preconditions that are applied mechanically, without looking to the context. Those guilty of this include $R$. HIGcINs, supra note 33, at 105; Bowett, Self-Determination and Political Right in De. veloping Countries, AM. Soc. INT'L L. 129, 131 (1966).

92. See M. McDougal \& Associates, Studies IN World Public Order 987 (1960):

By an international law of human dignity I mean the process of authoritative decision of a world public order in which values are shaped and shared more by persuasion than by coercion, and which seeks to promote the greatest production and widest pos. sible sharing, without discrimination irrelevant to merit, of all values among all human beings. 
set up a plebiscite. ${ }^{93}$ In still a third, it could demand the withdrawal of a foreign occupier, as it has done in the Namibia situation. ${ }^{3 t}$

Events will force the world community to deal with these problems, just as events have forced a recognition of the right of colonial peoples to independence. The Assembly already has the authority to deal with the problems of self-determination; the fact that until now it has concerned itself with only a small part of these problems merely demonstrates that the colonial territories have been the areas where the crisis has been most acute. As the focus of the problems shifts, so must the concern of the organized world community.

If the Assembly can effectively deal with these new problems as they arise, its concern with the establishment of rational criteria for the right of self-determination should cause great changes in the structure of the U.N. and the principles of international law. Two of these should be briefly mentioned, though one must remember that they are long-term projections. The justification for some optimism lies in the necessity for the organized world community to deal with broad issues of human rights in order to survive.

\section{A. Increased Power Sharing Within the United Nations}

The involvement of the Assembly with broad questions of selfdetermination and the evolution of standards to deal with these questions may well change the entire nature of the U.N. At the moment, most states use the Assembly podium primarily for propaganda, realizing that in most situations the U.N. is impotent and cannot affect world order. On matters of self-determination and human rights, however, the Assembly can and has acted as the moral conscience of the world community. Indeed, that was the role it assumed in the early Sixties in dealing with the colonial phenomena: It succeeded in transforming inchoate principles into normative rights by both enlightening and exerting pressure on major decision-makers; it con-

93. A plebiscite has been suggested as appropriate for dealing with Formosa. Chen \& Reisman, Who Owns Taizun: A Search for International Tille, 81 YaLE L.J. 599 (1972). Plebiscites, however, are open to abuse. The Namibia Court rejected South Africi's request for a plebiscite in South West Africa even though on the surface it vould appear an eminently reasonable way to ascertain the wishes of the inbabitants. However, in a police state where the machinery of control is geared to maintain white supremacy: it can serve no useful purpose. Even without the actual use of terror it vould be impossible to erase the fears of people who have been under colonial domination for so long. See F. Fanon, Black Skins, White Masks (1967); F. Fanon, THE Wretched of the EArti (1966).

94. U. UMozurike, supra note 6, at ch. 10, notes several arenas in which non-colonialist claims for self-determination are being made, including Somalia, Kashmir, and Nagaland; and diverse peoples claiming this right, including Sovict Jews, French Canadians, and Catholics in Northern Ireland. 
vinced them that their interests would be best served by ending colonial rule. In dealing with expanded concepts of human rights, much the same process must occur-convincing recalcitrant elites that national and international interests are best served by maximizing human dignity. This does not mean, however, that powerful states will fall captive to the smaller nations which now command a majority of the Assembly's votes. As in any parliamentary system, some will naturally exert greater influence than others.

\section{B. The Involvement of the Individual}

Since World War II, there has been a tremendous growth in the participation of the individual in international law. At one end of the spectrum, governments put individuals on trial at Nuremburg for crimes against humanity. At the other, individuals bring their states to the European Commission on Human Rights for violations of the basic standards of decency that a state must afford its citizens.

However, presently individuals may not appear as parties before the International Court nor may they address the major political organs of the U.N. If the U.N. attempts to deal with secessionist groups or with oppressed minorities, it should allow these groups to voice their grievances. This means moving away from a statecentered system which allows only the government to speak for its citizens. Due to the growing importance of human rights in the law, this process has already begun. ${ }^{95}$

It is Utopian to believe that a state will stand by and let other states turn over part of its territory to a rebellious group; but if the Assembly successfully evolves prescriptions so that these problems could be handled in their early stages, this extreme situation would rarely arise. The maximization of human dignity would obviate the desire to revolt in many instances. Of course, this is a lengthy process entailing an intense program of convincing state elites that allowing maximum group differentiation and participation will work to their advantage. One must expect some frustration, but the first step must involve the recognition of the primary importance of the individual in international law. Without such a recognition, it will be impossible to deal with the problems of self-determination that appear in the world today.

95. On a regional level, the European Commission on Human Rights receives petitions from individuals. In the U.N. several Committees also hear grievances of individuals. Recently, for the first time, a leader of a liberation army was accorded observer status at the United Nations by the Committee on Trusts and Nonselfgoverning Territories. N.Y. Times, Nov. 5, 1972, \& 1, at 10, col. 1 . 